\title{
Young Adults' Behaviour and Motivations toward Selfie-Posting
}

\section{Hayati Yusof ${ }^{1}$,Mai Farhana MiorBadrul Munir ${ }^{2}$ and Zulnurhaini Zolkaply ${ }^{3}$}

\author{
1,2,3 Department of Commerce and Accountancy, \\ Faculty of Business and Finance, UniversitiTunku Abdul Rahman, \\ 31900, Kampar, Perak, MALAYSIA
}

\begin{abstract}
Taking and posting selfies on Social Networking Sites (SNSs) have gained popularity recently. The SNSs have become a platform for users to build their online reputations and presence as desired regardless of its positive and negative outcomes. These acts may have boosted one's self-esteem and succeeded in gaining public attentions and acceptance. This research is conducted to test the Selfie-Stadium Model together with two independent variables - Self-Esteem (representing Social Comparison Theory) and Narcissism - to see their impacts on the young social media fans from the Malaysian diverse multicultural backgrounds. Interestingly, the young adults are quite humble, positive-minded and seem to be in control of themselves as a sign of maturity, in expressing their opinions on selfie-posting behaviour. This research is a contribution to the empirical sphere supported with quantitative data. It opens up more avenues for future researchers to test validated models to a different target audience, background and cultures.
\end{abstract}

Keywords:Selfie, Selfie-Posting Behaviour, Social Media, Young Adults, Selfie-Stadium Model, Narcissism

\section{Introduction}

Social networking sites (SNSs) such as Facebook, Instagram, and Twitter have reached tremendous growth and popularity in the past few years due to the ease of access to these platforms. In fact, SNSs have become the most commonly accessed websites on the Internet (Tiggemann \& Slater, 2014). However, a notable trend has emerged in SNSs these last few years where photo sharing has become a significant part of the online social experience. Since social media provides an arena for users presenting oneself (Kim \& Chock, 2017), posting selfies on social media has become a common and popular activity for users (Guo, Liu, Ding, Hu, Zhen, Liu \& Jiang, 2018). Social media users take the advantage of social media to create a forged identity with their desired self-related information by posting selfie (Chua \& Chang, 2016; Lyu, 2016). In other words, users present themselves online with a fabricated identity through selfies for social recognition (Burrow \&Rainone, 2017) and enhanced self-worth (Pounders, Kowalczyk \& Stowers, 2016). Due to this, "selfie" became word of the year for Oxford Dictionaries in 2013 (Shin, Kim, Im, \& Chong, 2017) which was defined as "a photograph that one has taken of oneself, typically with a smartphone or webcam and shared via social media" (Oxford Dictionaries, 2013).

\section{Problem Statement}

Nowadays, selfies could be seen as a globally popular cultural phenomenon (Chae, 2017). Winter (2014) revealed that more than 17 million selfies are uploaded to social media each week with currently around 439 million selfies can be found through \#selfie in the Instagram (Instagram, 2020). This becomes the witness of dramatic increase of selfie taking and posting behaviour. Furthermore, the advancement of technology gives a wide opportunity for people to present themselves online including presenting an identity that is totally different from offline identity. With the availability of tools and time, one can carefully select the information and the ideal identity to be presented for the online audience.

Aligned with the popularity of selfies, it earned a great attention from the academic scholars to examine the relationship between self-personality traits (such as self-esteem and narcissism) and selfie posting behavior. For example, a study found that those who post their selfies on social media used selfies as a self-esteem booster (Moneva, Perolino\&Ycong, 2020) as people can control how they are portrayed in their social network profile and hence they were able to increase their self-esteem momentarily (Gonzales \& Hancock, 2011). In contrast, Barry, Doucette, Loflin, Rivera-Hudson and Herrington (2017) revealed that there was no significant relationship between self-esteem levels and the number of selfie postings. It appeared that 
there is no difference on the willingness of individuals with low self-esteem and those with high self-esteem to post selfies on SNSs.

Besides, the existing scholarly literature had also focused upon the association of narcissism to the use of social media. The results reported from prior studies have shown positive association between narcissism and specific SNSs use including status updates or picture postings (Marshall, Lefringhausen, \& Ferenczi, 2015; Ryan \&Xenos, 2011). In fact, many studies have identified narcissism as an important predictor of selfie practices on SNSs (Weiser,2015). In contrast, in a more recent study by $\mathrm{Wu}$, Song, and $\mathrm{Ma}$ (2019) did not find any association between selfies and narcissism. As the previous research investigating those relationship have produced mixed results, this research is conducted to fill the gap by examining the effect of self-esteem and narcissism on selfie posting behavior and motivation among youth in Malaysia.

These two personality traits are used because there are commonalities between self-esteem and narcissism as pointed out by the prior studies (Campbell, 2001). In addition, as self-esteem and narcissism have frequently been proposed as important considerations in the rise of a selfie culture, empirical data on this issue are quite limited to date (Barry, et al., 2017). Besides, this study is conducted in Malaysia because many prior literature about selfie-posting behavior were done overseas such as studies involving the Instagram users in US public university (Barry et al., 2017), social media users in Turkish university (Arpaci,Yalçın, Baloğlu\&Kesici, 2018); Poland university and vocational schools (Sorokowski, Sorokowska, Frackowiak, Karwowski, Rusicka, \&Oleszkiewicz, 2016); USA university (Pounders, Kowalczyk, \& Stowers, 2016) and Australian university (March \&McBean, 2018); limited research was done in Malaysia.

In this sense, the study on what motivates the individual selfie-posting behavior had become a popular issue examined by many of the academic scholars previously. However, studies to date have rarely investigated the behavior that often comes preposting or before posting a selfie (Chae, 2017). Consciously, the investigation of pre-selfie-posting behavior leading up to the actual act of posting a selfie is important because constructing an online visual self-presentation is not only comprised of posting a selfie but is rather explained by the underlying behaviors related to constructing a selfie such as selecting the right photos and editing them for perfection before posting. Therefore, this research also profiles selfie-makers' motivation by applying the Selfie-Stadium Model as proposed by de Vaate, Veldhuis, Alleva, Konijn and Hugten (2018) in an attempt to find out the various steps taken by the young adults before actually posting a selfie. Overall, in this study, the researchers aimed to combine the front-stage and back-stage selfie posting behaviour and motivations as a back-to-back process as no research has done so in the past, at least, not to the knowledge of the researchers.

\subsection{Research Questions and Research Objectives}

Based on the problem statement, the research questions and research objectives are summarised as the following (Table 1):

Table 1: Research Questions and Research Objectives

\begin{tabular}{|c|c|}
\hline Research Question & Research Objective \\
\hline $\begin{array}{l}\text { 1. What is the relationship } \\
\text { between motive and } \\
\text { selection of selfie among } \\
\text { the social media users in } \\
\text { Malaysia? }\end{array}$ & $\begin{array}{l}\text { 1. To examine the } \\
\text { relationship between } \\
\text { motive and selection of } \\
\text { selfie among the social } \\
\text { media users in Malaysia. }\end{array}$ \\
\hline $\begin{array}{l}\text { 2. What is the relationship } \\
\text { between pre-occupation } \\
\text { and selection of selfie } \\
\text { among the social media } \\
\text { users in Malaysia? }\end{array}$ & $\begin{array}{l}2 . \text { To examine the } \\
\text { relationship between pre- } \\
\text { occupation and selection } \\
\text { of selfie among the social } \\
\text { media users in Malaysia. }\end{array}$ \\
\hline $\begin{array}{l}\text { 3. What is the relationship } \\
\text { between selection and } \\
\text { selfie editing among the } \\
\text { social media users in } \\
\text { Malaysia? }\end{array}$ & $\begin{array}{l}\text { 3. To examine the } \\
\text { relationship between } \\
\text { selection and selfie } \\
\text { editing among the social } \\
\text { media users in Malaysia. }\end{array}$ \\
\hline $\begin{array}{l}\text { 4. What is the relationship } \\
\text { between selfie editing and } \\
\text { selfie-posting behavior } \\
\text { among the social media } \\
\text { users in Malaysia? }\end{array}$ & $\begin{array}{l}\text { 4. To examine the } \\
\text { relationship between } \\
\text { selfie editing and selfie- } \\
\text { posting behavior among } \\
\text { the social media users in } \\
\text { Malaysia }\end{array}$ \\
\hline $\begin{array}{l}5 . \text { What is the relationship } \\
\text { between self-esteem and } \\
\text { selfie-posting behavior } \\
\text { among the social media } \\
\text { users in Malaysia? }\end{array}$ & $\begin{array}{l}\text { 5. To examine the } \\
\text { relationship between self- } \\
\text { esteem and selfie-posting } \\
\text { behavior among the social } \\
\text { media users in Malaysia. }\end{array}$ \\
\hline $\begin{array}{l}\text { 6. What is the relationship } \\
\text { between narcissism and } \\
\text { selfie-posting behavior } \\
\text { among the social media } \\
\text { users in Malaysia? }\end{array}$ & $\begin{array}{l}6 . \text { To examine the } \\
\text { relationship between } \\
\text { narcissism and selfie- } \\
\text { posting behavior among } \\
\text { the social media users in } \\
\text { Malaysia. }\end{array}$ \\
\hline
\end{tabular}

\section{Significance of Study}

The findings of this study are an addition to the empirical knowledge as it is backed up with quantitative analyses; it is a Social Science study involving human interactions with technology. Indirectly, technological developments change the way humans do things, in particular, taking photos, sharing them and keeping the memories. From the practical perspective, this study helps developers to explore other innovative ways to enhance the functions of their devices, making it safer or enjoying the flexibility of multitasking at one time. 


\section{Literature Review}

4.1 Early research on Self-Presentation (theory) Self-concept has been an important topic in psychology for a very long time. According to Markus and Wurf (1987), self-concept is constructed into two structures: core self-concept (characterized by stability) and working self-concept (characterized by flexibility and being influenced by the social settings). Core self-concept is more stable structure such as name, body self, roles and self-evaluation. On the other hand, working self-concept is a temporary and flexible structure that integrates the core self-concept with social stimuli. Brewer (1991) stated that there are two essential needs that people have, and these include the need to be similar to other (social self) and the need to be unique (personal self). In 1988, Carl Backman emphasized the transformation of self-concept in the context of social relations. This includes a personal and social self which is showing the image of unique aspect of self and about the groups to which individual belong. Self in this context modifies the experiences and mediate intrapersonal and interpersonal processes. According to Monteil and Martinot (1991), selfconcept is a knowing system about oneself and this topic has grown into many new concepts such as self-perception phenomenon (Bem, 1972), selfawareness (Wicklund, 1975) and self-monitoring (Snyder, 1979).

Social networking sites like Facebook and Instagram serves as platforms for selfies. Posting selfies online is a form of online self-presentation. In addition to sharing one's own profile, connecting to each other, and building relationships over a period of time, people also use social media for selfpresentation, self-exploration, and self enhancement (Amichai-Hamburger, 2007; Amichai-Hamburger \& Hayat, 2013). In cyberspace, social cognition approach can be adapted to the online selfpresentation for which individual presents personal self, social self, core self-concept and working selfconcept (Stanculescu, 2011). Early research on selfpresentation by Goffman (1978) suggested that social behaviors can be identified as differing in front stage and back stage behaviors. Individuals tend to behave in ways to meet other's expectations in the front stage behavior; meanwhile, back stage is referring to the place where front behaviors are prepared. Stanculescu(2011) added that online selfpresentation could contain self-serving bias as people have the tendency to present positive light about themselves such as competent, successful, attractive, and social skillful person.

4.2 Steps in Selfie-Posting Behaviour - The Selfie-Stadium Model (Independent Variables)

\section{ISSN 2455-6378}

This research is trying to understand the selfieposting behaviour and the motivation by applying the Selfie-Stadium Model proposed by de Vaateet al., (2018). All the steps in this model are: Motives, Preoccupation, Selection and Editing have been adopted in this study.

\subsubsection{Motives}

In the Selfie-Stadium Model, Motive is the first step in the process of selfie making. Individuals must have motives or reasons for making selfies before they can make self-presentations on any social networking sites. Many studies have shown a variety of motives in selfie making such as attention seeking, to fulfill social needs and self-expression (Sung, Lee, Kim \& Choi, 2016). This step also applies the literature on social functions of personal photographs in general and Facebook to understand the motives of taking and sharing selfies on SNS such as Facebook. According to Van House,Davis, Ames, Finn and Viswanathan (2005), people share pictures for self-presentation, self-expression, to reflect existing relationships, to maintain relationship and to cultivate a new one. Based on these various motives, this study aims to investigate the underlying motives of selfie-posting behaviour.

\subsubsection{Pre-occupation}

In this model, de Vaateet al., (2018) also presented Pre-occupation as another step taken together with Motive and it is referring to the involvement of individuals in selfie-posting behaviour on SNS. Such behaviours are looking at selfies, tagging, sharing and commenting on selfies of others which the authors believe will direct individual perceptions of desired behaviour on selfies. Meier and Gray (2014) also defined pre-occupation as the willingness of individuals to look at other people's selfie and give comments.

\subsubsection{Selection}

The next step in the selfie-process is selecting the best own-self selfies to be posted on SNS. Impression management drives people to consciously select selfies and to present themselves through selected pictures that can make them look the best. In another perspective, Chen, Schaffer and Wu (1997) highlighted that attractive face influences social cognition for which attractive face people tends to be more favourable traits than those who are less attractive.

\subsubsection{Editing}

The last step in selfie taking as dictated in the SelfieStadium Model is Editing. This step is used to create a better physical appearance of individuals for the purpose of self-presentation. There are many software applications that enable individuals to 
beautify pictures before posting it publicly on SNS. With good-looking pictures, SNS users are more likely to receive higher responds and attentions from others for example comments and likes (Salomon, 2013). Therefore, Editing has been proposed by de Vaateet al. (2018) as the last step before individuals post their selfie picture online.

\subsection{Social Comparison Theory}

Another part of this study has adopted the Social Comparison Theory in understanding the posting behaviour and motivation of selfies. In 1954, Festinger introduced Social Comparison Theory to describe how people ease insecurity in specific circumstances by comparing themselves to others and to examine theway of human self-defined. The drive of human beings to achieve their opinions and understand their abilities leads to comparisons with others when they are incapable of evaluating their views and abilities (Festinger, 1957). This theory initially contains comparisons of opinions and abilities but then it has expanded to include other features such as emotions (Gibbons \&Buunk, 1999). The researchers also argues that people with certain personalities have high tendency of doing social comparison. Among those traits are high narcissism and low self-esteem (Buunk\& Gibbons, 2007). The direction of comparison is either upward or downward comparison. Upward comparison defines self-comparison with others that are better than ownself while downward comparison defines selfcomparison with others that are worse than own-self (Festinger, 1957). Among all media, social media is one of the platforms that allows social comparison to take place (Shin et al., 2017).

Some previous studies have applied Social Comparison Theory in different areas. Gentina, Huarng and Sakashita (2018) employed Social Comparison Theory on mothers' clothing coconsumption behaviors. The finding showed that the level of self-esteem has positive impact on mothers' clothing co-consumption practices with teenage daughters. Powell, Wang-Hall, Bannister, Colera and Lopez (2018) applied Social Comparison Theory to women's body image concerns. They found that social comparison significantly influenced women's body satisfaction. Moreover, Chen, Lu and Zhang (2017) applied Social Comparison Theory in explaining individual's driving behaviors. It showed that social comparison significantly related with role of status which reflects on driving behavior as highstatus car reduces the traffic violations. Two significant dimensions of Social Comparison Theory are Social Sensitivity and Self-Esteem. This study employs Self-Esteem to explain selfie-posting behavior.
ISSN 2455-6378

\subsubsection{Self-Esteem}

Self-Esteem is one of the dimensions of Social Comparison Theory and this dimension has been used in developing the research framework of this study. There are quite a number of definitions of Self-Esteem by many researchers. Shin et al., (2017) defined Self-Esteem as the evaluation of individuals on their self-worth or adequacy as well as satisfaction. Other researchers also defined SelfEsteem as an evaluation or judgement of selfworthiness of individuals (Coopersmith,1967; Rosenberg, 1979). A highly satisfaction of selfevaluation meant high Self-Esteem, while low SelfEsteem refers to dissatisfaction to oneself (Baumeister, Campbell, Krueger, \&Vohs, 2003). The social comparison mostly occurs in social media due to people can easily display themselves, communicate and provide feedback to others on social media (Shin et al., 2017). For instance, individuals tend to post selfies on social media to enhance their Self-Esteem due to feedback received from others which reflects on number of 'likes' that they will receive (Pounders et al., 2016). Therefore, Self-Esteem is influenced by the result of social comparison.

\subsection{Narcissism}

Narcissism is distinguished as overload self-love, respect, and overstated attention to the self (Guedes, 2017). Since the narcissists tend to pursue out consideration to maintain their self-enhancement, they are more likely to produce self-promoting content that can carry desired self-views and post publicly on the SNS (Kim \& Chock, 2017). They found that Narcissism works as a key predictor of incentives for selecting and posting selfies that focus social attraction and physical for both men and women. Further empirical evidence was provided by Wang (2017) who found that more narcissistic people expressed larger amounts of Facebook exercises and posted more self-promoting substance on their profiles. It is reasonable to state that Narcissism was positively affected by selfie-posting behavior.

The term Narcissism was used and first made by Ellis in 1898 and this term was merged into a theory which is in his article 'On Narcissism'. Narcissism is distinguished as overload self-love, respect, and overstated attention to the self. Narcissists tend to increase their value, achievement, and recognition (Guedes, 2017).In addition, narcissists seek self-improvementthrough interpersonal relationships by establishing themselves with others (Moon, Lee, Lee, Choi \& Sung, 2016) and using their social relationships to look appealing and high-status (Arpaci, et al., 2018).

Furthermore, Narcissism identifies with the exemplary perspective of the condition, particularly 
with regards to initiative since narcissists have an expanded perspective of them and frequently think they are superior to anything they are (Guedes, 2017). In addition, narcissists embrace extravagant but uneven views of their abilities, individuality, and social application, which they preserve through selfcentered and exhibitionistic judgements and arrangements (Buss \& Chiodo, 1991).

Since selfie taking and posting behavior permits people on specifically exhibit appealing and self-promoting photographs of themselves (Chua \& Chang, 2016; March \&Mcbean, 2018), it is achievable that such conduct would be more typical in those with high narcissism. The action of choosing selfies and posting them on SNS may work as a selfie taking and posting behavior through which narcissists try to meet their target (McCain, Borg, Rothenberg, Churillo, Weiler\& Campbell, 2016).

Besides, Narcissism has been found to be a strong predictor of selfie taking and posting behaviors. Many recent studies have repeatedly shown that Narcissism to be reflected in selfieposting behavior and it is significantly and positively associated with selfie posting activities (e.g., Halpern, Valenzuela \&Katz, 2016; Lee \& Sung, 2016), content-specific (Grosz,Lösch, \& Back, 2017), and users' self-disclosure (Halpernet al.,2016).

\subsection{Selfie-Posting Behaviour and Motivation (Dependant Variable)}

The aim of this study is to understand the psychological impetus of the selfie-posting behaviour and motivation, which is the dependent variable of this study. There are many factors that have been found linked to the selfie-posting behaviour and motivation in the previous research. According to Charoensukmongkol (2016), loneliness, attention seeking, and self-centered behavior have a strong relationship with selfieposting behavior. Thus, this study intended to examine the psychological antecedents of taking and posting selfies to comprehend the underlying mechanism. Selfie-posting on social media also can be indicated as an online activity of self-promoting (Biolcati\&Passini, 2018). Selfie-posting behavior has been described as the way of individuals visually present themselves to netizens on social media (de Vaateet al., 2018). According to Barry et al. (2017), selfie-posting is a normal behavior for social media users because photo sharing is an important part of the online social experience. Thus, this study aimed to examine the determinants that motivating individuals' selfie-posting behavior.

4.6 Proposed Research Framework

Based on the Reviewof Literature, Figure 1 portrays the proposed research framework.

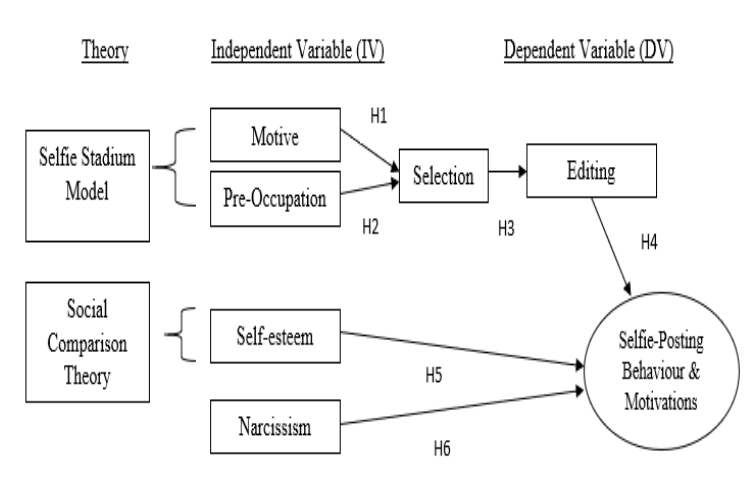

Fig. 1: Proposed Research Framework

Based on Review of Literature and the proposed research framework (Figure 1), six hypotheses have been developed and tested. They are:

H1: There is a positive and significant relationship between Motive and Selection

$\mathrm{H} 2$ : There is a positive and significant relationship between Pre-Occupation and Selection

H3: There is a positive and significant relationship between Selection and Editing

H4: There is a positive and significant relationship between Editing and Selfie-Posting Behaviour and Motivations

H5: There is a positive and significant relationship between Self-Esteem and Selfie-Posting Behavior and Motivations

H6: There is a positive and significant relationship between Narcissism and Selfie-Posting Behavior and Motivations

\section{Research Methodology}

\subsection{Pilot Study}

A pre-testing of the questionnaire was conducted in December 2020. 40 respondents took part in the pilot test in order to prove its reliability (Molla\& Licker, 2005). Table 2 below shows the results of the pilot test according to the research variables. Based on the result, the Cronbach's coefficient alpha values of dependent variables (DV) and independent variables are ranging from 0.655 to 0.955 . It indicates that Motive (MO) has the highest reliability of variable while Selfie-Posting Behaviourand Motivations (SP) has the lowest. 
Table 2: Pilot Test result of Reliability

\begin{tabular}{|l|c|}
\hline \multicolumn{1}{|c|}{ Variables } & $\begin{array}{c}\text { Cronbach's Coefficient } \\
\text { Alpha Value }\end{array}$ \\
\hline Motive (MO) & 0.955 \\
\hline Pre-Occupation (PR) & 0.685 \\
\hline Selection (SE) & 0.850 \\
\hline Editing (ED) & 0.854 \\
\hline Self-Esteem (SF) & 0.768 \\
\hline Narcissism (NC) & 0.715 \\
\hline $\begin{array}{l}\text { Selfie-Posting Behaviour } \\
\text { (SP) and Motivations }\end{array}$ & 0.655 \\
\hline
\end{tabular}

\subsection{Research Design}

The purpose of this research is to find out the selfieposting behaviour and motivations among Malaysian youth. The targeted respondents were private university students aged between 19-30 years as these groups represent the digital natives. A crosssectional research was done as it allowed researchers to conduct research faster and in a cost-effective manner (Setia, 2016) especially during the COVID19 lockdown durations. As a result of that, the online questionnaire using Google forms was used to collect primary data from all respondents.

\subsection{Data Collection Method}

Since this research is quantitative in nature, data collection using a survey questionnaire will be suitable for the researchers. A Google form was used for this purpose.

\subsubsection{Sampling Design}

In Malaysia, the highest smartphone owners (53.5\%) are aged between $20-34$ with $84.8 \%$ smartphone adoption rate(Internet Users Survey, 2017) and the highest Internet users are aged between 20-24 and the top online activities are text communication, social media, voice or video communication, watching videos and searching for information (Internet Users Survey, 2020). They represent digital natives of Malaysia. Considering the time constraint and the lockdown durations between January to March 2021, this research has chosen the private university students as its sample. Based on item-toresponse ratio, the recommended sample size is 320 , however, only 282 respondents took part and completed the questionnaires.

\subsection{Data Analysis}

The collected data will be analysed in a Descriptive manner, testing its Reliability, adopting Pearson Correlations, Normality Tests, Multiple Linear

\section{ISSN 2455-6378}

Regressions and One-way analysis of variance (ANOVA).

\subsubsection{Descriptive Analysis}

Descriptive statistics summarise and manage the data into an easily understood manner but do not draw any inference of the whole population from the selected sample (Narkhede, 2018). Descriptive statistics involved the measurements of frequencies that simply count how many times that each variable occurs (Korb, 2013); measures of central tendency include the mean, median and mode; measures of variability include the standard deviation (or variance), the minimum and maximum values of the variables, kurtosis and skewness (Wikipedia, n.d.).

\subsubsection{Reliability Test}

Reliability test aimed at examining the consistency of variables using Cronbach's Alpha. According to Sekaran and Bougie (2013), the closer the Cronbach's Alpha value approaches 1.0, the higher the reliability of variables.

\subsubsection{Pearson Correlation}

Pearson Correlation analysis is applied to measure the strength of the relationship between two variables and their association with each other. In other words, Pearson Correlation analysis is applied to explore the relationship between two variables, $\mathrm{X}$ and $\mathrm{Y}$ (variables) and calculates the effect of change in one variable when the other variable changes. However, when coefficient values among the IVs exceed 0.9, then, multicollinearity problem will occur (Hair, Anderson, Tatham, \& Blank, 1998).

\subsubsection{Normality Test}

Normality test is employed to examine if IVs and DV are normally distributed. Skewness and kurtosis are used for the test in the study. Skewness measures the degree of symmetry (Sheskin, 2011), and kurtosis measures the extent of the tail in the distribution of variables (Westfall, 2014). According to Garson (2012), the data is normally distributed if the skewness and kurtosis values are within \pm 2 .

\subsubsection{Multiple Linear Regression (MLR)}

$\mathrm{R}^{2}$ is used to determine how well the independent variables (IVs) can be explained by the dependent variable (DV). Hair, Babin, Money and Samouel(2013) defines that $\mathrm{R}^{2}$ value of $0.75,0.5$ or 0.25 in PLS path model as considerable, reasonable or weak separately.

\subsubsection{One-way Analysis of Variance (ANOVA)} One-way ANOVA is a type of statistical test that compares the variance in the group means within a sample whilst considering only one independent variable or factor. It is a hypothesis-based test, 
meaning that it aims to evaluate multiple mutually exclusive theories about the data (Mackenzie, 2018).

\section{Results and Discussion}

Next, the results of data analysis will be presented, followed by discussions on the findings. This section has been divided according to the following: Demographic Profile of Respondents, Reliability Analysis, Pearson Correlation Analysis, Central Tendencies Measurement of Constructs, Normality Test, Multiple Linear Regression and Variance Analysis for the Model Summary and One-way Analysis of Variance for each variable in the research framework

\subsection{Demographic Profile of the Respondents} In total, 282 undergraduate students studying in a private university took part in this research (Table 3). From the 282 students, majority of the respondents were female students $(67 \%, 189$ respondents) while male students comprised about 33\% (93 students). Their age ranged from 19 years old $(8.9 \%, 25$ students), 20 years old $(47.5 \%, 134$ students), 21 years old $(31.6 \%, 89$ students), 22 years old $(6.7 \%$, 19 students) and older (5.4\%, 15 students). More than half of the respondents were Instagram fans (71.3\%, 201 respondents), followed by $16 \%$ (45 respondents) Facebook users and $12.1 \%$ (34 respondents) owned more than one SNS or have social media accounts other than Facebook, Instagram and Twitters.

Table 3: Demographic Profile of the Respondents

\begin{tabular}{|c|c|c|}
\hline Gender & Frequency & $\begin{array}{c}\text { Percentage } \\
(\%)\end{array}$ \\
\hline Male & 93 & 33 \\
\hline Female & 189 & 67 \\
\hline Age & Frequency & $\begin{array}{c}\text { Percentage } \\
(\%)\end{array}$ \\
\hline 19 years old & 25 & 8.9 \\
\hline 20 & 134 & 47.5 \\
\hline 21 & 89 & 31.6 \\
\hline 22 & 19 & 6.7 \\
\hline 23 & 7 & 2.5 \\
\hline 24 & 5 & 1.8 \\
\hline 25 & 2 & 0.7 \\
\hline 26 & 1 & 0.4 \\
\hline $\begin{array}{r}\text { Types of Social } \\
\text { Networking } \\
\text { Sites (SNS) } \\
\end{array}$ & Frequency & $\begin{array}{c}\text { Percentage } \\
(\%)\end{array}$ \\
\hline Facebook & 45 & 16 \\
\hline Instagram & 201 & 71.3 \\
\hline Twitter & 2 & 0.7 \\
\hline $\begin{array}{l}\text { Own more than } \\
\text { one SNS/ Other } \\
\text { SNS }\end{array}$ & 34 & 12.1 \\
\hline TOTAL & 282 & 100 \\
\hline
\end{tabular}

6.2 Central Tendencies Measurement of Constructs

Table 4 indicates the mean and standard deviation for all items in each construct. The mean values of Motive ranged from 2.5355 to 3.8936 , PreOccupation ranged from 2.6206 to 3.7340 , Selection ranged from 2.3085 to 3.7695 , Editing ranged from 2.0106 to 3.3759 , Self-Esteem ranged from 3.3191 to 3.7624, Narcissism ranged from 2.8475 to 3.4326 and the Selfie-Posting Behaviourand Motivations ranged from 1.7270 to 4.1277 .

The results for Motive to take selfies showed that most respondents slightly disagreed or neutral to almost agreed, while for Pre-Occupation (involved in tagging or looked at selfies posted by others), most respondents showed slightly disagreed to almost agreed. In Selection (the reasons for taking or posting selfie), most respondents showed from disagreements to almost agreed, while in Editing the photos, most respondents were in-between disagreements and being neutral.

In addition, for the feeling of one's Self-Esteem, most respondents chose from being neutral to almost agreed and for being a narcissistic, most respondents showed that they were in-between disagreements to being neutral. Lastly, for the Selfie-Posting Behaviour, the range indicated the preferred time to post a selfie, number of selfies posted and the types of selfies taken.

Table 4: Central Tendencies Measurement of Construct

\begin{tabular}{|c|c|c|c|c|}
\hline Variable & Item & N & Mean & $\begin{array}{c}\text { Standard } \\
\text { Deviation }\end{array}$ \\
\hline Motive (MO) & MO1 & 282 & 3.8936 & 0.89444 \\
& MO2 & & 3.6170 & 0.82798 \\
& MO3 & & 3.5816 & 0.85335 \\
& MO4 & & 2.8404 & 0.89247 \\
& MO5 & & 2.9858 & 0.83505 \\
& MO6 & & 2.8901 & 0.87592 \\
& MO7 & & 2.8475 & 0.85297 \\
& MO8 & & 3.2057 & 0.79606 \\
& MO9 & & 3.2270 & 0.83405 \\
& MO10 & & 3.4965 & 0.92513 \\
& MO11 & & 3.2199 & 0.86112 \\
& MO12 & & 3.4504 & 0.85164 \\
MO13 & & 3.2234 & 0.92979 \\
& MO14 & & 2.8972 & 1.06383 \\
& MO15 & & 2.7589 & 1.08959 \\
& MO16 & & 2.8404 & 1.00146 \\
& MO17 & & 3.0461 & 0.90942 \\
& MO18 & & 3.0461 & 0.92878 \\
& MO19 & & 3.0248 & 0.81974 \\
& MO20 & & 3.1064 & 0.85789 \\
& MO21 & & 3.0638 & 0.81980 \\
MO22 & & 3.0284 & 0.87221 \\
& MO23 & & 3.0248 & 0.83693 \\
& MO24 & & 2.5355 & 0.90892 \\
MO25 & & 2.9787 & 0.86833 \\
& MO26 & & 3.0993 & 0.83351 \\
& MO28 & & 3.0000 & 0.92417 \\
& & 2.6241 & 0.90502 \\
& MO30 & & 2.7730 & 0.96463 \\
& & 2.6879 & 0.93287 \\
& & 2.8298 & 0.93913 \\
\hline
\end{tabular}




\begin{tabular}{|c|c|c|c|c|}
\hline $\begin{array}{c}\text { Pre- } \\
\text { Occupation } \\
\text { (PR) }\end{array}$ & $\begin{array}{l}\text { PR1 } \\
\text { PR2 } \\
\text { PR3 } \\
\text { PR4 } \\
\text { PR6 }\end{array}$ & 282 & $\begin{array}{l}3.7340 \\
3.6525 \\
3.2411 \\
3.0567 \\
2.6206\end{array}$ & $\begin{array}{l}0.74283 \\
0.73534 \\
0.87594 \\
0.91077 \\
0.94398\end{array}$ \\
\hline Selection (SE) & $\begin{array}{c}\text { SE1 } \\
\text { SE2 } \\
\text { SE3 } \\
\text { SE4 } \\
\text { SE5 } \\
\text { SE6 } \\
\text { SE7 } \\
\text { SE8 } \\
\text { SE9 } \\
\text { SE10 } \\
\text { SE11 } \\
\text { SE12 } \\
\text { SE13 } \\
\end{array}$ & 282 & $\begin{array}{l}3.3617 \\
3.2943 \\
3.6418 \\
3.7695 \\
3.5780 \\
3.5674 \\
3.4149 \\
3.3794 \\
3.4610 \\
3.2766 \\
2.3085 \\
3.0567 \\
2.9716 \\
\end{array}$ & $\begin{array}{l}0.68825 \\
0.84485 \\
0.77512 \\
0.73066 \\
0.86609 \\
0.78514 \\
0.81021 \\
0.85288 \\
0.93958 \\
0.88969 \\
0.92062 \\
0.82032 \\
0.88437 \\
\end{array}$ \\
\hline Editing (ED) & $\begin{array}{l}\text { ED1 } \\
\text { ED2 } \\
\text { ED3 } \\
\text { ED4 }\end{array}$ & 282 & $\begin{array}{l}3.3759 \\
2.9610 \\
3.1596 \\
2.0106 \\
\end{array}$ & $\begin{array}{l}1.03352 \\
1.01689 \\
1.05341 \\
0.89476 \\
\end{array}$ \\
\hline $\begin{array}{l}\text { Self-Esteem } \\
\text { (SF) }\end{array}$ & $\begin{array}{c}\text { SF1 } \\
\text { SF3 } \\
\text { SF4 } \\
\text { SF7 } \\
\text { SF8 } \\
\text { SF10 } \\
\end{array}$ & 282 & $\begin{array}{l}3.3830 \\
3.3191 \\
3.3972 \\
3.4113 \\
3.7624 \\
3.7340 \\
\end{array}$ & $\begin{array}{l}0.83653 \\
0.77615 \\
0.75344 \\
0.83577 \\
0.73325 \\
0.73318 \\
\end{array}$ \\
\hline $\begin{array}{c}\text { Narcissism } \\
\text { (NC) }\end{array}$ & $\begin{array}{c}\mathrm{NC} 1 \\
\mathrm{NC} 2 \\
\mathrm{NC} 3 \\
\mathrm{NC} 4 \\
\mathrm{NC} 5 \\
\mathrm{NC} 6 \\
\mathrm{NC} 7 \\
\mathrm{NC} 8 \\
\mathrm{NC} 9 \\
\mathrm{NC} 10 \\
\end{array}$ & 282 & $\begin{array}{l}3.4326 \\
3.2234 \\
3.1418 \\
3.0496 \\
3.0887 \\
3.1383 \\
3.0709 \\
2.8688 \\
3.0071 \\
2.8475 \\
\end{array}$ & $\begin{array}{l}0.70892 \\
0.92979 \\
0.87741 \\
0.71413 \\
0.69257 \\
0.72477 \\
0.70731 \\
0.83548 \\
0.93181 \\
0.84036 \\
\end{array}$ \\
\hline $\begin{array}{l}\text { Selfie-Posting } \\
\text { Behaviourand } \\
\text { Motivations } \\
\text { (SP) }\end{array}$ & $\begin{array}{l}\text { SP1 } \\
\text { SP2 } \\
\text { SP3 } \\
\text { SP4 } \\
\text { SP5 } \\
\text { SP6 } \\
\text { SP7 } \\
\text { SP8 } \\
\text { SP9 }\end{array}$ & 282 & $\begin{array}{l}4.1277 \\
1.7270 \\
1.8050 \\
3.6064 \\
3.3014 \\
3.4326 \\
2.8227 \\
2.2411 \\
2.8723\end{array}$ & $\begin{array}{l}1.10225 \\
0.91250 \\
0.88538 \\
0.85060 \\
0.93827 \\
0.93035 \\
1.01086 \\
0.92725 \\
1.12146\end{array}$ \\
\hline
\end{tabular}

\subsection{Reliability Analysis}

Based on Table 5, the Cronbach Alpha coefficient values ranged from 0.542 to 0.929 . The highest value is Motive (MO) which is 0.929 , followed by Selection 0.867 while among the lowest are PreOccupation (0.639) and Selfie-Posting Behaviour and Motivations (0.542) itself. For survey items to be considered reliable and consistent, Cronbach Alpha value should be 0.7 (Heale\& Twycross, 2015; Sekaran \& Bougie, 2013).

\section{Table 5: Reliability Test}

\begin{tabular}{|l|c|l|c|}
\hline $\begin{array}{c}\text { Independent } \\
\text { Variable }\end{array}$ & $\begin{array}{c}\text { Cronbach } \\
\text { Alpha }\end{array}$ & $\begin{array}{c}\text { Dependent } \\
\text { Variable }\end{array}$ & $\begin{array}{c}\text { Cronbach } \\
\text { Alpha }\end{array}$ \\
\cline { 1 - 2 } Motive (MO) & 0.929 & \multirow{2}{\text{Selfie-Posting}}{} & 0.542 \\
\cline { 1 - 2 } $\begin{array}{l}\text { Pre- } \\
\text { Occupation } \\
\text { (PR) }\end{array}$ & 0.639 & $\begin{array}{l}\text { Behaviourand } \\
\text { Motivations } \\
\text { (SP) }\end{array}$ & \\
\hline Selection & 0.867 & & \\
\hline
\end{tabular}

ISSN 2455-6378

\begin{tabular}{|l|c|l|l|}
\hline$(\mathrm{SE})$ & & \multirow{5}{*}{} & \\
\hline Editing (ED) & 0.764 & & \\
\cline { 1 - 2 } $\begin{array}{l}\text { Self-Esteem } \\
\text { (SF) }\end{array}$ & 0.832 & & \\
\cline { 1 - 2 } $\begin{array}{l}\text { Narcississm } \\
\text { (NC) }\end{array}$ & 0.735 & & \\
\hline
\end{tabular}

\subsection{Pearson Correlation Analysis}

To determine the relationship between two variables which are continuous such as Motive to Selection, Pearson Correlation analysis is conducted. Referring to Table 6 , all correlation values signified that they had positive correlations. The highest correlation value was 0.658 (Motive to Selection) and the lowest correlation was 0.111 (Narcissism to Selfie-Posting Behaviour and Motivations). In conclusion, there was no multicollinearity problem faced as all scores were below 0.9 .

Table 6: Pearson Correlation Analysis

\begin{tabular}{|c|c|}
\hline Variable & $\begin{array}{c}\text { Pearson Correlation } \\
\text { Results }\end{array}$ \\
\hline $\begin{array}{l}\text { Motive (MO) } \rightarrow \text { Selection } \\
(\mathrm{SE})\end{array}$ & $\begin{array}{l}0.658 \\
\text { Significant at the } 0.01 \text { level }\end{array}$ \\
\hline $\begin{array}{lll}\text { Pre-Occupation } & \text { (PR) } & \rightarrow \\
\text { Selection (SE) } & & \end{array}$ & $\begin{array}{l}0.645 \\
\text { Significant at the } 0.01 \text { level }\end{array}$ \\
\hline $\begin{array}{l}\text { Selection }(\mathrm{SE}) \rightarrow \text { Editing } \\
(\mathrm{ED})\end{array}$ & $\begin{array}{l}0.277 \\
\text { Significant at the } 0.01 \text { level }\end{array}$ \\
\hline $\begin{array}{l}\text { Editing (ED) } \rightarrow \text { Selfie- } \\
\text { Posting } \\
\text { Motivations (SP) }\end{array}$ & $\begin{array}{l}0.218 \\
\text { Significant at the } 0.01 \text { level }\end{array}$ \\
\hline $\begin{array}{l}\text { Self-Esteem }(\mathrm{SF}) \rightarrow \text { Selfie- } \\
\text { Posting } \quad \text { Behaviourand } \\
\text { Motivations (SP) }\end{array}$ & $\begin{array}{l}0.230 \\
\text { Significant at the } 0.01 \text { level }\end{array}$ \\
\hline $\begin{array}{l}\text { Narcississm (NC) } \rightarrow \text { Selfie- } \\
\text { Posting Behaviour } \\
\text { Motivations (SP) }\end{array}$ & $\begin{array}{l}0.111 \\
\text { Significant at the } 0.05 \text { level }\end{array}$ \\
\hline
\end{tabular}

\subsection{Normality Test}

To determine whether the data have normal distribution, normality test was conducted and the skewness and kurtosis values for all construct items were derived. Based on Table 7, the highest value for skewness was 1.757 (SP2) and the lowest value was -0.901 (MO1). By contrast, the highest value for kurtosis was 3.656 (SP2) and the lowest value was 0.765 (MO14). In summary, the skewness and kurtosis for all items fulfilled the benchmark of \pm 2.00 which mean they were normally distributed except for two items, SP2 (the number of selfies taken and posted to social media for the past 30 days) and SP3 (the number of other photos taken and posted on social media for the past 30 days).

Upon checking, most respondents humbly admitted that they either posted zero to ten selfies, or some posted up to 20 selfies in the past 30 days (between January to March 2021). A very small number of respondents admitted that they have taken and posted more than 20 selfies or other photos (up to 30 selfies or photos) during the same duration. 
Table 7: Normality Test

\begin{tabular}{|c|c|c|c|}
\hline Construct & Items & Skewness & Kurtosis \\
\hline \multirow[t]{31}{*}{ Motive (MO) } & MO1 & -0.901 & 1.217 \\
\hline & MO2 & -0.510 & 0.639 \\
\hline & MO3 & -0.603 & 0.584 \\
\hline & MO4 & 0.107 & 0.029 \\
\hline & MO5 & -0.195 & -0.326 \\
\hline & MO6 & 0.056 & -0.192 \\
\hline & MO7 & 0.020 & -0.282 \\
\hline & MO8 & -0.429 & -0.082 \\
\hline & MO9 & -0.447 & 0.202 \\
\hline & MO10 & -0.411 & -0.127 \\
\hline & MO11 & -0.373 & 0.005 \\
\hline & MO12 & -0.418 & 0.114 \\
\hline & MO13 & -0.111 & -0.221 \\
\hline & MO14 & -0.043 & -0.765 \\
\hline & MO15 & 0.076 & -0.724 \\
\hline & MO16 & -0.082 & -0.419 \\
\hline & MO17 & -0.377 & -0.201 \\
\hline & MO18 & -0.199 & -0.061 \\
\hline & MO19 & -0.202 & 0.827 \\
\hline & MO20 & -0.274 & -0.129 \\
\hline & MO21 & -0.197 & 0.067 \\
\hline & MO22 & -0.055 & -0.180 \\
\hline & MO23 & -0.304 & 0.326 \\
\hline & MO24 & 0.367 & -0.209 \\
\hline & MO25 & -0.090 & -0.308 \\
\hline & MO26 & -0.337 & -0.200 \\
\hline & MO27 & -0.082 & -0.461 \\
\hline & $\mathrm{MO} 28$ & 0.177 & -0.148 \\
\hline & MO29 & 0.181 & -0.330 \\
\hline & MO30 & 0.236 & -0.031 \\
\hline & MO31 & 0.060 & -0.255 \\
\hline \multirow{5}{*}{$\begin{array}{l}\text { Pre-Occupation } \\
\text { (PR) }\end{array}$} & PR1 & -0.420 & 0.368 \\
\hline & PR2 & -0.430 & 0.616 \\
\hline & PR3 & -0.202 & -0.140 \\
\hline & PR4 & 0.001 & -0.552 \\
\hline & PR6 & 0.134 & -0.246 \\
\hline \multirow[t]{13}{*}{ Selection (SE) } & SE1 & 0.178 & -0.096 \\
\hline & SE2 & 0.111 & -0.117 \\
\hline & SE3 & 0.026 & -0.462 \\
\hline & SE4 & 0.002 & -0.474 \\
\hline & SE5 & -0.193 & -0.139 \\
\hline & SE6 & -0.091 & 0.070 \\
\hline & SE7 & 0.197 & -0.421 \\
\hline & SE8 & -0.018 & -0.179 \\
\hline & SE9 & -0.392 & -0.055 \\
\hline & SE10 & -0.420 & 0.052 \\
\hline & SE11 & 0.369 & -0.039 \\
\hline & SE12 & -0.144 & 0.527 \\
\hline & SE13 & -0.100 & 0.039 \\
\hline \multirow[t]{4}{*}{ Editing (ED) } & ED1 & -0.492 & -0.293 \\
\hline & ED2 & -0.106 & -0.559 \\
\hline & ED3 & -0.231 & -0.566 \\
\hline & ED4 & 0.940 & 1.056 \\
\hline \multirow[t]{6}{*}{ Self-Esteem (SF) } & SF1 & -0.268 & 0.486 \\
\hline & SF3 & -0.025 & 0.452 \\
\hline & SF4 & 0.053 & -0.053 \\
\hline & SF7 & -0.122 & 0.077 \\
\hline & SF8 & -0.032 & -0.422 \\
\hline & SF10 & -0.193 & 0.125 \\
\hline \multirow[t]{10}{*}{ Narcissism (NC) } & $\mathrm{NC} 1$ & -0.243 & 1.045 \\
\hline & $\mathrm{NC} 2$ & 0.022 & -0.410 \\
\hline & NC3 & -0.185 & -0.017 \\
\hline & $\mathrm{NC} 4$ & -0.191 & 1.018 \\
\hline & NC5 & -0.054 & 0.767 \\
\hline & NC6 & 0.010 & 0.016 \\
\hline & NC7 & -0.344 & 0.503 \\
\hline & $\mathrm{NC} 8$ & -0.081 & -0.214 \\
\hline & NC9 & -0.227 & -0.229 \\
\hline & $\mathrm{NC} 10$ & -0.213 & 0.377 \\
\hline
\end{tabular}

ISSN 2455-6378

\begin{tabular}{|l|c|c|c|}
\hline Selfie-Posting & SP1 & -0.785 & -0.800 \\
Behaviourand & SP2 & 1.757 & 3.656 \\
Motivations (SP) & SP3 & 1.539 & 3.031 \\
& SP4 & -0.301 & 0.008 \\
& SP5 & -0.505 & 0.121 \\
& SP6 & -0.376 & 0.186 \\
& SP7 & -0.054 & -0.475 \\
& SP8 & 0.446 & -0.116 \\
& SP9 & -0.097 & -0.706 \\
\hline
\end{tabular}

6.6 Multiple Linear Regression (MLR) - Model Summary

Table 8 indicated that $27.9 \%$ of Selfie-Posting Behaviour and Motivations are explained by the six independent variables chosen in this research. Indirectly, $72.1 \%$ of Selfie-Posting Behaviour and Motivations are influenced by other factors not captured by the research.

Table 8: MLR - Model Summary

\begin{tabular}{|c|c|c|c|c|}
\hline Model & R & R Square & $\begin{array}{c}\text { Adjusted } \\
\text { R } \\
\text { square }\end{array}$ & $\begin{array}{c}\text { Std. error } \\
\text { of the } \\
\text { Estimate }\end{array}$ \\
\hline 1 & $.528^{\mathrm{a}}$ & .279 & .264 & 3.46351 \\
\hline a. Predictors: (Constant), IV1MOT, IV3SELF, IV4NAR,
\end{tabular}
IV6EDIT, IV2PRE, IV5SEL

\subsection{Analysis of Variance (ANOVA) - Model} Summary

Table 9 is the analysis of variance involving all six variables and Selfie-Posting Behaviourand Motivations (dependant variable). The overall Fvalue is significant at 17.756 ( $\mathrm{p}$-value is $<0.05$ ), hence, the model fit in this research is achieved. It can be concluded that the six chosen variables had influenced Selfie-Posting Behaviour and Motivations.

Table 9: Analysis of Variance (ANOVA) - Model Summary

\begin{tabular}{|c|c|c|c|c|c|}
\hline Model & Sum of Squares & df & Mean Square & $\bar{F}$ & $\begin{array}{c}\text { Sig } \\
\text { (p-ralue) }\end{array}$ \\
\hline $\begin{array}{l}1 \text { Regression } \\
\text { Residual } \\
\text { Total }\end{array}$ & $\begin{array}{l}1277.978 \\
3298.873 \\
4576.851\end{array}$ & $\begin{array}{c}6 \\
275 \\
281\end{array}$ & $\begin{array}{c}212.996 \\
11.996\end{array}$ & 17.756 & $.000^{\mathrm{a}}$ \\
\hline
\end{tabular}

6.8 One-way Analysis of Variance (ANOVA) on Each Variable

In the next section, the strength of the relationship between variables have been conducted using oneway analysis of variance (ANOVA).

\subsubsection{From Motive to Selection}

H1: There is a positive and significant relationship between Motive and Selection

Based on Table 10, since the F-value is 4.773 (pvalue is $<0.05$ ), it is concluded that there is a positive and significant relationship between Motive and Selection. Thus, H1 is accepted. 
Table 10: Analysis of Variance - from MOTIVE to SELECTION

\begin{tabular}{|l|c|c|c|c|c|}
\hline & Sum of Squares & df & Mean Square & F & $\begin{array}{c}\text { Sig } \\
\text { (p-value) }\end{array}$ \\
\hline Between Groups & 6415.470 & 66 & 97.204 & 4.773 & .000 \\
Within Groups & 4378.973 & 215 & 20.367 & & \\
Total & 10794.443 & 281 & & & \\
\hline
\end{tabular}

\subsubsection{From Pre-Occupation to Selection}

H2: There is a positive and significant relationship between Pre-Occupation and Selection

Based on Table 11, the F-value is 12.199 (p-value is $<0.05$ ), it can be concluded that there is a positive and significant relationship between Pre-Occupation and Selection. Hence, $\mathrm{H} 2$ is accepted.

Table 11: Analysis of Variance - from PRE-OCCUPATION to SELECTION

\begin{tabular}{|l|c|c|c|c|c|}
\hline & Sum of Squares & df & Mean Square & F & $\begin{array}{c}\text { Sig } \\
\text { (p-value) }\end{array}$ \\
\hline Between Groups & 4749.074 & 17 & 279.357 & 12.199 & .000 \\
Within Groups & 6045.369 & 264 & 22.899 & & \\
Total & 10794.443 & 281 & & & \\
\hline
\end{tabular}

\subsubsection{From Selection to Editing}

H3: There is a positive and significant relationship between Selection and Editing

Based on Table 12, the F-value is 2.134 (p-value is $<0.05$ ), it can be said that there is a positive and significant relationship between Selection and Editing. Therefore, H3 is accepted.

Table 12: Analysis of Variance - from SELECTION to EDITING

\begin{tabular}{|l|c|c|c|c|c|}
\hline & Sum of Squares & df & Mean Square & F & $\begin{array}{c}\text { Sig } \\
\text { (p-value) }\end{array}$ \\
\hline Between Groups & 331.074 & 32 & 10.346 & 2.134 & .001 \\
Within Groups & 1207.071 & 249 & 4.848 & & \\
Total & 1538.145 & 281 & & & \\
\hline
\end{tabular}

6.8.4 From Editing to Selfie-Posting Behaviour and Motivations

H4: There is a positive and significant relationship between Editing and Selfie-Posting Behaviour and Motivations

Table 13 shows that for Editing and Selfie-Posting Behaviour and Motivations, the F-value is 2.719 (pvalue is $<0.05$ ), it is concluded that there is a positive and significant relationship between Editing and Selfie-Posting Behaviour and Motivations. Thus, H4 is accepted.

Table 13: Analysis of Variance - from EDITING to SELFIEPOSTING BEHAVIOUR AND MOTIVATIONS

\begin{tabular}{|l|c|c|c|c|c|}
\hline & Sum of Squares & df & Mean Square & F & $\begin{array}{c}\text { Sig } \\
\text { (p-value) }\end{array}$ \\
\hline $\begin{array}{l}\text { Between Groups } \\
\text { Within Groups } \\
\text { Total }\end{array}$ & 495.124 & 12 & 41.260 & 2.719 & .002 \\
\hline
\end{tabular}

6.8.5From Self-Esteem to Selfie-Posting Behaviour and Motivations
ISSN 2455-6378

H5: There is a positive and significant relationship between Self-esteem and Selfie-Posting Behavior and Motivations

For Self-Esteem to Selfie-Posting Behaviour and Motivations, Table 14 shows the F-value of 2.499 (pvalue is <0.05), hence, there is a positive and significant relationship between Self-Esteem and Selfie-Posting Behaviour and Motivations, leading to the acceptance of H5.

Table 14: Analysis of Variance - from SELF-ESTEEM to SELFIE-POSTING BEHAVIOUR AND MOTIVATIONS

\begin{tabular}{|l|c|c|c|c|c|}
\hline & Sum of Squares & df & Mean Square & F & $\begin{array}{c}\text { Sig } \\
\text { (p-value) }\end{array}$ \\
\hline Between Groups & 668.427 & 18 & 37.135 & 2.499 & .001 \\
Within Groups & 3908.424 & 263 & 14.861 & & \\
Total & 4576.851 & 281 & & & \\
\hline
\end{tabular}

6.8.6 From Narcissism to Selfie-Posting Behaviour and Motivations

H6: There is a positive and significant relationship between Narcissism and Selfie-Posting Behavior and Motivations

For the last hypothesis, Table 15 shows an F-value of 3.194 ( $p$-value is $<0.05$ ) for the relationship between Narcissism and Selfie-Posting Behaviour and Motivations. It can be assumed that there is a positive and significant relationship between Narcissism and Selfie-Posting Behaviour and Motivations, hence, H6 is also accepted.

Table 15: Analysis of Variance - from NARCISSISM to SELFIEPOSTING BEHAVIOUR AND MOTIVATION

\begin{tabular}{|l|c|c|c|c|c|}
\hline & Sum of Squares & df & Mean Square & F & $\begin{array}{c}\text { Sig } \\
\text { (p-value) }\end{array}$ \\
\hline $\begin{array}{l}\text { Between Groups } \\
\text { Within Groups }\end{array}$ & 1051.537 & 24 & 43.814 & 3.194 & .000 \\
Total & 3525.314 & 257 & 13.717 & & \\
\hline
\end{tabular}

\subsection{Multiple Linear Regression on Hypotheses}

The followings are the Multiple Linear Regression analysis on the six hypotheses or variables.

6.9.1From Motive and Pre-Occupation to Selection

From Table 16, 52.8\% of selfie Selection task was influenced by both Motive and Pre-Occupation, while the other $47.2 \%$ of Selection was influenced by other factors outside of this research.

Table 16: Multiple Linear Regression - from MOTIVE and PREOCCUPATION to SELECTION

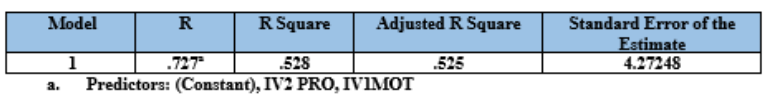

\subsubsection{From Selection to Editing}

Based on Table 17, only $7.7 \%$ of Selection contributed towards selfie Editing task. It means that 
the other $92.3 \%$ of Editing is determined by nonSelection factors, not measured in this research.

Table 17: Multiple Linear Regression - from SELECTION to EDITING

\begin{tabular}{|c|c|c|c|c|}
\hline Model & $\bar{R}$ & R Square & Adjusted R Square & $\begin{array}{c}\text { Standard Error of the } \\
\text { Estimate }\end{array}$ \\
\hline 1 & $.277^{2}$ & .077 & .073 & 2.25220 \\
\hline
\end{tabular}

6.9.3 From Editing, Self-Esteem and Narcissism to Selfie-Posting Behaviour and Motivations

The finding indicated that Editing, Self-Esteem and Narcissism only contributed $9.1 \%$ towards SelfiePosting Behaviourand Motivations of the Malaysian youth (Table 18). It also means that $90.9 \%$ of other factors excluding in this research actually may have influenced the youth's decision to take and post a selfie.

Table 18: Multiple Linear Regression - from EDITING, SELFESTEEM and NARCISSISM to SELFIE-POSTING BEHAVIOUR AND MOTIVATIONS

\begin{tabular}{|c|c|c|c|c|}
\hline Model & $\mathbf{R}$ & R Square & Adjusted R Square & $\begin{array}{c}\text { Standard Error of the } \\
\text { Estimate }\end{array}$ \\
\hline $\mathbf{l}$ & $.302^{\mathbf{2}}$ & .091 & .081 & 3.86805 \\
\hline \multicolumn{2}{|c|}{ a. Predictors: (Constant), IV6EDIT, IV3SELF, IV4NAR } \\
\hline
\end{tabular}

\subsection{Discussion}

In a multicultural country like Malaysia, with different beliefs, religions and family backgrounds, its young adults are quite humble and neutral, not to show off or being highly pressured by peers to post selfies. Posting selfies are to capture the memories like visiting famous places, meeting interesting people, photos taken with families and friends at a gathering or event. Many disagreed with posting selfies is to show expensive brands or showing body parts, clothing or posture to look sexy as these actsare influenced by its culture and upbringing.

Many young adults also could not care to edit their photos, as to show their photos naturally or being genuine; perfection is not a prioritywith these young adults which is different from Salomon (2013). In terms of post-posting behaviour like Self-Esteem, the youth seemed positive about themselves. This is consistent with Baumeister et al., (2003). In addition, these digital natives are quite in control of themselves that they did not post selfies as an act of selfishness, to be at the centre of everyone's attention or are too in love with themselves, thus, contrasting Arpaciet. al.'s (2018) profiles.

The six variables that have been chosen in this research (four variables belong to the SelfieStadium Model or the pre-posting steps) indicated a small influence for the Malaysian young adults to post selfies. Indirectly, it signaled for other reasons for them to post selfies that have not been captured by this research such as business or commercial reasons, online jobs, careers, projects, competitions,

\section{ISSN 2455-6378}

exhibitions, etc. This is because young children in Malaysia are exposed to entrepreneurial and competitive spirits at an early age from family business, school entrepreneurship programmes, sports and competitions and technology in education. It can be said here that the Selfie-Stadium Model might need further validation or extension to be applied in the Malaysian or Asian culture.

Eventhough all the six hypotheses are supportedand the steps are relevant as according to de Vaateet al., (2018) but the degree of influencevaries individually. For example, only 7.7\% of Selection influenced Editing (Table 17) indicating other reasons to edit, or possibly Editing is not the right step after Selection. Furthermore, 9.1\% of Editing, Self-Esteem and Narcissism influenced Selfie-Posting Behaviour and Motivations (Table 18) may have signaled for a different combination of factors or variables in order to strongly influenced social media users to post selfies.

\section{Conclusion and Future Direction}

In conclusion, this research adopted and combined Selfie-Stadium Models with two other variables (Self-Esteem and Narcissism) and tested it to the Malaysian young audience. In general, all six hypotheses were supported with various degree of influence. However, this research is cross-sectional with only a small number of respondents that belong to a private university who took part. The researchers encourage more testing of the Selfie-Stadium Model with further validation and revision on its steps to other, larger group of social media users in probably other Asian countries.

\section{Appendix}

Nil.

\section{Acknowledgments}

Special thanks to Kok Xin Yi, Lim Pui Koon, Tan Hui Yi, Tan Shu Xin and Wong Weng Hong who have initiated the first ground study.

\section{References}

[1] Amichai-Hamburger,Personality, individual differences and Internet use. The Oxford handbook of Internet psychology, 187204,(2007).

[2] Amichai-Hamburger and Hayat,Internet and personality. In AmichaiHamburger (Eds.), The social net: Understanding our online, Oxford University Press. Oxford, UK, pp.1-20, (2013).

[3] Arpaci, Yalçın, Baloğlu, Kesici, The moderating effect of gender in the relationship between narcissism and selfie-posting behavior. 
Personality and Individual Differences, 134, 7174, (2018).

[4] Barry,Doucette, Loflin, Rivera-Hudson and Herrington, (2017). "Let me take a selfie": Associations between self-photography, narcissism, and self-esteem. Psychology of popular media culture, Vol 6(Issue 1): 48-60, (2017).

[5] Baumeister,Campbell, Krueger andVohs,Does high self-esteem cause better performance, interpersonal success, happiness, or healthier lifestyles?.Psychological Science In The Public Interest, Vol 4(Issue 1): 1-44, (2003).

[6] Bem,Self - Perception: An Alternative Interpretation of Cognitive Disonance Phenomena.Psychological Review, Vol 74 (Issue 3): 183 - 200, (1972).

[7] Biolcati andPassini, Narcissism and self-esteem: Different motivations for selfie posting behaviors. Cogent Psychology, Vol 5 (Issue 1),(2018). https://doi.org/10.1080/23311908.2018.1437012

[8] Brewer,(1991). The social self: On being the same and different at the same time. Personality and social psychology bulletin, Vol 17(Issue 5) : 475-482, (1991).

[9] Buss and Chiodo, Narcissistic acts in everyday life. Journal of Personality, Vol 59 (Issue 2): 179-215, (1991).

[10] Buunk and Gibbons, Social comparison: The end of a theory and the emergence of a field. Organizational Behavior and Human Decision Processes, Vol 102(Issue 1):3-21, (2007).

[11] Burrow andRainone, How many likes did I get?: Purpose moderates links between positive social media feedback and self-esteem. Journal of Experimental Social Psychology, Vol 69: 232236, (2017).

[12] Campbell, Is narcissism really so bad? Psychological Inquiry, Vol 12(Issue 4): 214216, (2001).

[13] Chae, Virtual makeover: Selfie-taking and social media use increase selfie-editing frequency through social comparison. Computers in Human Behavior, Vol 66: 370-376, (2017). doi:10.1016/j.chb.2016.10.007.

[14] Charoensukmongkol,Exploring personal characteristics associated with selfie-liking. Cyber psychology: Journal of Psychosocial Research on Cyberspace, Vol 10 (Issue 2): 210217, (2016).

[15] Chen, Schaffer and Wu,On physical attractiveness stereotyping in Taiwan: A revised sociocultural perspective. Journal of Social Psychology, Vol 137 (Issue 1): 117 - 124, (1997).

[16] Chen, Lu and Zhang, Social comparison, status and driving behaviour. Journal of Public Economics, Vol 155: 11-20, (2017).

[17] Chua and Chang, Follow me and like my beautiful selfies: Singapore teenage girls' engagement in self-presentation and peer comparison on social media. Computers in Human Behavior, Vol 55: 190-197, (2016).

\section{ISSN 2455-6378}

[18] Coopersmith, The antecedents of self-esteem. San Francisco: Freeman, (1967).

[19] de Vaate, Veldhuis, Alleva, Konijn, and van Hugten, Show your best self (ie): An exploratory study on selfie-related motivations and behavior in emerging adulthood. Telematics and Informatics, Vol 35(Issue 5): 1392-1407, (2018).

[20] Festinger,Social comparison theory. Selective Exposure Theory, 16, (1957).

[21] Garson,Testing Statistical Assumptions. Asheboro, NC: Statistical Associates Publishing, (2012).

[22] Gentina,Huarng andSakashita,A social comparison theory approach to mothers' and daughters' clothing co-consumption behaviors: A cross-cultural study in France and Japan. Journal of Business Research, Vol 89: 361-370, (2018).

[23] Gibbons andBuunk, 1999). Individual differences in social comparison: Development of a scale of social comparison orientation. Journal of Personality and Social Psychology, Vol 76(Issue 1): 129-142, (1999).

[24] Goffman, The presentation of self in everyday life. London: Harmondsworth, pp. 56, (1978).

[25] Gonzales and Hancock, Mirror, mirror on my Facebook wall: Effects of Facebook exposure on self-esteem. Cyberpsychology, Behavior, and Social Networking, Vol 14: 79-83, (2011).

[26]Grosz, Lösch, and Back, The narcissismoverclaiming link revisited. Journal of Research in Personality, Vol 70: 134-138, (2017).

[27] Guedes, Mirror, mirror on the wall, am I the greatest performer of all? Narcissism and selfreported and objective performance. Personality and Individual Differences, Vol 108: 182-185, (2017).

[28] Guo, Liu,Ding, Hu, Zhen, Liu and Jiang,How are extraversion, exhibitionism, and gender associated with posting selfies on WeChat friends' circle in Chinese teenagers? Personality and Individual Differences, Vol 127: 114-116, (2018).

[29] Hair, Anderson, Tatham and Blank, Multivariate data analysis (5th ed.). New Jersey: PrenticeHall, (1998).

[30] Hair, Babin, Money and Samouel,Essentials of business research methods (1st ed.). New Jersey: John Wiley \& Sons, Inc, (2013).

[31]Halpern,Valenzuela and Katz,"Selfieists"or"Narci-selfiers"? A crosslagged panel analysis of selfie taking and narcissism. Personality and Individual Differences, Vol 97: 98-101, (2016).

[32] Heale and Twycross, Validity and reliability in quantitative studies. Evidence-based nursing, Vol 18(Issue 3): 66-67, (2015).

[33] Instagram. selfie[website]. Retrieved 30 December 2020 from https://www.instagram.com/explore/tags/selfie/

[34] Kim and Chock,Personality traits and psychological motivations predicting selfie posting behaviors on social networking sites. Telematics and Informatics, Vol 34(Issue 5): 560-571, (2017). 
[35] Korb,Conducting educational research: calculating descriptive statistics, (2013). Retrieved 1 January 2021, from http://korbedpsych.com/R17bDescriptive.html

[36] Lee and Sung,Hide-and-seek: Narcissism and"selfie"-related behavior. Cyberpsychology, Behavior and Social Networking, Vol 19(Issue 5): 347-351, (2016).

[37] Lyu, Travel selfies on social media as objectified self-presentation. Tourism Management, Vol 54: 185-195, (2016).

[38] Mackenzie,One-way vs two-way ANOVA: Differences, Assumptions and Hypotheses, (2018). Retrieved 27 April 2021 from https://www.technologynetworks.com/informatic s/articles/one-way-vs-two-way-anova-definitiondifferences-assumptions-and-hypotheses-306553

[39] March and McBean,New evidence shows selfesteem moderates the relationship between narcissism and selfies. Personality and Individual Differences, Vol 130: 107-111, (2018).

[40] Markus and Wurf, The dynamic self-concept: A social psychological perspective. Annual review of psychology, Vol 38(Issue 1): 299-337, (1987).

[41] Marshall, Lefringhausen and Ferenczi, The Big Five, self-esteem, and narcissism as predictors of the topics people write about in Facebook status updates. Personality and Individual Differences, Vol 85: 35-40, (2015).

[42] MCMC, Internet Users Survey, (2017). Retrieved on 1 May 2021 from https://www.mcmc.gov.my/skmmgovmy/media/ general/pdf/mcmc-internet-users-survey2017.pdf

[43] MCMC, Internet Users Survey, (2020). Retrieved on 1 May 2021 from https://www.mcmc.gov.my/skmmgovmy/media/ General/pdf/IUS-2020-Report.pdf

[44] Mccain, Borg, Rothenberg,Churillo, Weiler and Campbell, Personality and selfies: Narcissism and the Dark Triad. Computers in Human Behavior, Vol 64: 126-133, (2016).

[45] Meier and Gray,Facebook photo activity associated with body image disturbance in adolescent girls. Cyberpsychology, Behavior, and Social Networking, Vol 17(Issue 4): 199206, (2014).

[46] Molla and Licker,Ecommerce adoption in developing countries: A model and instrument. Information \& Management, Vol 42(Issue 6): 877-899, (2005).

[47] Moneva, Perolino, andYcong, Selfie and SelfEsteem. International Journal of Social Science Research, Vol 8(Issue 2): 131-142, (2020).

[48] Monteil and Martinot,Le soi et sesproprietes.Psychologiefrançaise, Vol 36: 55 66, (1991).

[49]Moon, Lee,Lee,Choiand Sung, The role of narcissism in self-promotion on Instagram. Personality and Individual Differences, Vol 101: 22-25, (2016).

[50] Narkhede,Understanding descriptive analysis, (2018). Retrieved 1 January 2021 from https://towardsdatascience.com/understandingdescriptive-statistics-c9c2b0641291

\section{ISSN 2455-6378}

[51] Oxford Dictionaries, Selfie, (2013). Retrieved on 1 May 2021 from http://www.oxforddictionaries. $\mathrm{com} /$ definition/english/selfie

[52] Pounders, Kowalczyk and Stowers, Insight into the motivation of selfie postings: impression management and self-esteem. European Journal of Marketing, Vol 50(Issue 9/10): 1879-1892, (2016).

[53] Powell, Wang-Hall, Bannister, Colera and Lopez,Attachment security and social comparisons as predictors of Pinterest users' body image concerns. Computers in Human Behavior, Vol 83: 221-229, (2018).

[54] Rosenberg,Conceiving the self. New York: Basic Books, (1979).

[55] Ryan andXenos, Who uses Facebook? An investigation into the relationship between the Big Five, shyness, narcissism, loneliness, and Facebook usage. Computers in Human Behavior, Vol 27(Issue 5): 1658-1664, (2011).

[56] Salomon,Moving on from Facebook: Using Instagram to connect with undergraduates and engage in teaching and learning. College \& Research Libraries News, Vol 74(Issue 8): 408412, (2013).

[57] Sekaran and Bougie,Research methods for business: A skill-building approach (6th ed.). New York: John Wiley \& Sons, (2013).

[58] Setia,Methodology Series Module 3: Crosssectional Studies [Electronic version]. India Journal of Dermatology, Vol 61(Issue 3): 261264, (2016).doi: 10.4103/0019-5154.182410

[59] Sheskin,Handbook of parametric and nonparametric statistical procedures (5th ed.), London : Chapman \& Hall/CRC, (2011).

[60] Shin, Kim, Im, and Chong, Selfie and self: The effect of selfies on self-esteem and social sensitivity. Personality and Individual Differences, Vol 111: 139-145, (2017).

[61] Sorokowski, Sorokowska,Frackowiak, Karwowski, Rusicka and Oleszkiewicz,Sex differences in online selfie posting behaviors predict histrionic personality scores among men but not women. Computers in Human Behavior, Vol 59: 368-373, (2016).

[62] Stănculescu,Online self-presentation from the cyberpsychology perspective. In Conference proceedings ofeLearning and Software for Education (eLSE), No. 01: 155-160, "Carol I" National Defence University Publishing House, (2011).

[63] Sung,Lee, Kim and Choi,Why we post selfies: Understanding motivations for posting pictures of oneself. Personality and Individual Differences, Vol 97: 260-265, (2016).

[64] Snyder,Self-Monitoring Processes. In Berkowitz, L. (Ed.), Advances in Experimental Social Psychology, Vol 12:86 - 131, (1979).

[65] Tiggemann and Slater, 2014). NetTweens: The internet and body image concerns in preteenage girls. The Journal of Early Adolescence, Vol 34: 606-620, (2014).

[66] Van House,Davis, Ames,Finn and Viswanathan,The uses of personal networked digital imaging: an empirical study of 
cameraphone photos and sharing. In CHI'05 extended abstracts on Human factors in computing systems: 1853-1856, (2005, April).

[67] Wang,A study of the relationshipbetweennarcissism, extraversion, drive for entertainment, and narcissisticbehavior on social networking sites. Computers in Human Behavior, Vol 66: 138-148, (2017).

[68] Westfall, Kurtosis as peakedness, 1905-2014. RIP, The American Statistician, Vol 68(Issue 3): 191-195, (2014).

[69] Weiser,\#Me: Narcissism and its facets as predictors of selfie-posting frequency. Personality and Individual Differences, Vol 86: 477-481, (2015).

[70] Wicklund,Objective Self-Awareness. In Berkowitz, L. (Ed.), Advances in Experimental SocialPsychology,Vol 8:233 - 275, (1975).

\section{ISSN 2455-6378}

[71] Wikipedia, Descriptive Statistics, (n.d.). Retrieved $27 \quad$ April 2021 from https://en.wikipedia.org/wiki/Descriptive_statisti cs

[72] Winter,We're all selfie-obsessed! Over 17 million self-portraits uploaded to social media every week-with over-55s taking more than those ages 18-24 [news item], (2014, March 26). Retrieved $27 \quad$ April 2021 from http://www.dailymail.co.uk/femail/article2536597/Were-selfie-obsessed-Over-17-millionself-portraits-uploaded-social-media-week-55staking-aged-18-24.html

[73] $\mathrm{Wu}$, Song and Ma,Selfie taking may be nonharmful: Evidence from adaptive and maladaptive narcissism among Chinese young adults. Human Behavior and Emerging Technologies, Vol 1(Issue 3): 240-244, (2019). 